\title{
- REVISTA BRASILEIRA DE ENFERMAGEM - 60 ANOS DE EXISTÊNCIA
}

Em 20 de maio de 1992 a REBEn completará 60 anos. Fundada em 1932 com o nome de "Anais de Enfermagem", teve como principal incentivadora, Edith de Magalhães Fraenkel (na época presidente da Associação Nacional de Enfermeiras Diplomadas Brasileiras-ANEDB) e como 1? redatora-chefe, Rachel Haddock Loho.

Historicamente, a nossa Revista sempre se sustentou no desejo dos dirigentes e sócios da ABEn em manter o veículo oficial de divulgação da Associação Brasileira de Enfermagem.

Interrompida algumas vezes, em conseqüência de dificuldades de diversas ordens, a REBEn sempre buscou alternativas para permanecer viva e preservar o seu espaço, já garantido, como divulgadora do saber em enfermagem.

Energias foram dispendidas nesses sessenta anos, por todos aqueles que ousaram acreditar e manter ativa a REBEn. Como qualquer outra publicação em nosso país, a Revista Brasileira de Enfermagem vive em crise permanente.

Assim, por diversas vezes, necessitou a REBEn condensar em uma só publicação 3 numeros, para viabilizar a continuidade de edição e não privar o contato leitor/Revista.

Na gestão 89/92, a REBEn foi pensada dentro do sistema de assinaturas, com aprovação em AND. Para desenvolver um empreendimento de tal magnitude, contou o Conselho Editorial com o apoio da diretoria da ABEn-Nacional, dos órgãos financiadores (CNPQ e FINEP), das seções, regionais e dos sócios da ABEn.

Os sócios da ABEn demonstraram total confiança no projeto, mandando suas críticas e sugestóes, enviando trabalhos e sensibilizando a categoria quanto à importância da assinatura da Revista.

O esforço dos membros do Conselho Editorial foi imensurável, pois rompeu obstáculos, até aqui, intransponiveis. Todos, com o firme propósito de concretizar o projeto, não titubearam em ahandonar suas horas de lazer para juntos vencerem mais uma etapa da sua Revista.

Contamos sempre com o incentivo das Escolas de Enfermagem e, em especial, nesta gestão, com o apoio da Escola de Enfermagem da IJFF. Esta Escola, num todo, não mediu esforços para auxiliar o trabalho da Revista, colocando-se à disposição do Conselho Editorial. Acreditava que só o trabalho conjunto poderia viabilizar a regularização da REBEn e manter sua periodicidade.

Hoje temos como recompensa deste esforço, a puhlicação do 7 exemplares, fruto de um trabalho proficuo de todos aqueles que, direta ou indiretamente, contribuiram com a REBEn.

Aos 60 anos, a REBEn mantêm-se jovem, hela, ousada e denunciante de que a construção, o enriquecimento da experiência e o avançar dependem de participação consciente nas lutas travadas cotidianamente; reflexiva e aberta a contribuiçóes para que o processo participativo represente um crescer harmônico e capaz de sintonizar-se com os anseios da categoria e da sociedade em geral.

Jane da Fonseca Proença Coordenadora da Comissão de Publicações e Divulgação da ABEn-Nacional 